\title{
Techno-economic and environmental evaluation of demand side management techniques for rural electrification in Ibadan, Nigeria
}

\author{
Tolulope O. Akinbulire • Peter Olabisi Oluseyi • \\ Olubayo Moses Babatunde
}

Received: 3 January 2014 / Accepted: 23 June 2014/Published online: 2 August 2014

(C) The Author(s) 2014. This article is published with open access at Springerlink.com

\begin{abstract}
According to the United Nation Development Programme, access to modern low-cost energy systems in developing countries is important in the realization of the globally agreed developmental goals, as well as the Millennium Development Goals, and sustainable development, which would assist in the reduction of poverty and to improve the conditions and quality of life for the greater part of the world's population. Planners have suggested hybrid energy system for the electrification of rural areas worldwide. This study investigates the techno-economic and environmental effect of applying demand side management (DSM) activities to rural loads before design and sizing of hybrid energy systems for such community. Iporin a rural area in Ibadan, Nigeria which is endowed with an average daily solar radiation of $3.84 \mathrm{kWh} / \mathrm{m}^{2} /$ day was taken as a case study. The total daily consumption which was initially estimated as $297 \mathrm{kWh} /$ day after the application of DSM techniques dropped to $130 \mathrm{kWh} /$ day representing a decrease of $56.80 \%$. Hybrid Optimization Model for Electric Renewables software was used for simulation and optimization purpose. Parameters such as DSM index, net present cost, and emission level were used in determining the effect of the DSM technique. Overall, the DSM activities proved to be more economical and environmental friendly.
\end{abstract}

\footnotetext{
T. O. Akinbulire · P. O. Oluseyi · O. M. Babatunde ( $\square)$

Department of Electrical/Electronic Engineering,

University of Lagos, Lagos, Nigeria

e-mail: olubayobabatunde@gmail.com

T. O. Akinbulire

e-mail: takinbulire@unilag.edu.ng

P. O. Oluseyi

e-mail: poluseyi@unilag.edu.ng
}

Keywords Hybrid energy system - Demand side management · Energy efficiency · HOMER · Nigeria

\section{Background}

There is an increasing anxiety with regard to the fundamental changes in energy equilibrium for meeting the growing energy demand with the available energy resources. Several nations have engaged the researchers to sort out this challenge. Nigeria as the largest country in Africa with a population of about 148 million is also facing this challenge. This is because not less than $60 \%$ of the population has limited or no access to electricity, hence there is need to stem the energy crisis in the nation [1]. Due to the increasing population of Nigeria, there has been a corresponding increase in power demand without a reliable supply to meet such. The short fall in the supply of electricity in this country especially in the rural settlement where there are inadequate or no grid systems necessitates the need to explore renewable source of energy. Reference [2] ascertains that stand-alone photovoltaic (PV) system configuration offers an economical substitute to the costly grid extensions in rural areas in the world.

The use of renewable energy system is a very significant option for power providers in rural electrification program. To accommodate the unpredictable nature of the renewable energy sources, hybrid systems can be applied. These systems consist of diverse energy combination of generators, thereby maintaining a stable energy supply in times of shortages of one of the energy resources. The major advantage credited to these systems is the great potential it has for economic development [3]. Apart from the fact that it aids economic development, it eliminates the cost of installing grid system to isolated rural areas. It also ensures 
a high level of reliability and a sustainable environment by limiting the emission of $\mathrm{CO}_{2}$ [4]. However, the assessments of the accurate configuration of renewable energy mix need to be analyzed in such a way as to ensure that the system is adequately optimized and effectively utilized.

International Energy Agency (IEA) data for 2009 point out that electrification rates for Nigeria stood at $50 \%$. According to this data, about 76 million of her population does not have access to uninterrupted electricity [1]. This represents about $51.4 \%$ of the total population. Eighty percent of this is from the rural areas where the majority of the food products consumed in the urban areas are produced. When considering only rural areas, $50 \%$ of the population in rural areas in Nigeria lives below the poverty line [5]. In the year 2012, the United Nations development programme (UNDP) identified rural electrification as a means of improving the quality of life and the eradication of poverty [6].

The management of resources has been a bane of development; so there is a great burden to ensure that energy is equitably shared to all, irrespective of economic status of individuals. As advocated by the UNDP in 2012, right to modern low-cost energy system in developing countries is important for the realization of the globally agreed developmental goals, as well as the Millennium Development Goals, and sustainable development, which would assist in the reduction of poverty and to improve the quality and standard of life for the greater part of the world's population [6]. Hence, there is need for sustainable rural electrification using the locally available resources.

A major step in achieving this is the application of energy-efficient techniques to all loads being utilized by rural consumers. Efficient energy utilization should be seen as an immediate and cost-efficient source of new energy supply as cost of generating energy can be several times the cost of conserving it. Energy efficiency does not only include the physical efficiency of the technical equipment and facilities, but also the overall proper energy usage and economic efficiency of the energy system. Energy efficiency entails the deployment of expertise that requires a reduced amount of energy to carry out the same task. Energy efficiency and conservation practices contribute to the minimization of carbon footprint [7]. The practices targeted to achieve such efficiency are known as demand side management (DSM). In developing countries such as Nigeria, there is generally inadequate or lack of awareness of energy efficiency, conservation and DSM programmes.

\section{Demand side management}

The practices targeted to achieve such efficiency are known as demand side management (DSM). DSM are such activities carried out to influence either the quantity or time pattern of energy consumption in ways to increase customer satisfaction and modify or reduce end-users' energy demand $[8,9]$. DSM is the implementation of strategies and procedures which tend to control, influence and usually cut energy consumption. DSM targets to improve appliance consumption, trim down utilization, while maintaining an equivalent level of service and pleasure [10]. DSM has been acknowledged as a key solution in the battle against climatic change given that energy use and peak load demand are reduced, and with a reduction of conventional energy, carbon footprint is reduced.

Application of DSM to energy consumption in a wider range can also bring about noteworthy cost benefits to energy end-users and subsequent reductions in carbon emissions [11]. There are several ways in reducing energy consumption in all energy-consuming sectors, many of which are inexpensive, or even at no cost. The enthusiasm that forms the basis for the implementation of energy efficiency measures is evidently different for the various participating parties. For utility companies, it can be deduced as avoiding or delaying installation of supplementary generating capacity while for energy consumers, DSM offers the prospect of reduction in energy bill.

The major types of DSM practices may be classified into three groups $[9,12,13]$ namely: energy reduction programmes (reducing demand through more efficient processes, buildings or equipment); load management programmes (changing the load pattern and encouraging less demand at peak times and peak rates); load growth and conservation programmes. DSM load management objectives are: peak clipping, load shifting, valley filling, energy conservation, strategic load growth, and flexible load shape [14]. In all, DSM programs have the main goal of reshaping the load curve to make it as flat as possible. This study among other things will tend to answer the research question: "considering the available resources and energy efficiency measures, how can hybrid energy be optimized to solve the problem of lack of or inadequate electricity supply in rural communities?"

Many studies have dealt with the optimal sizing of hybrid energy for rural electrification without considering the effect of DSM [15-18]. Against this background, the main purpose of this study is to evaluate the technical, economic and environmental benefits of applying DSM activities in the sizing of hybrid energy systems for rural electrification. It compares the present electricity consumption of the community with the proposed DSM measures.

Energy management opportunities in residential areas

\section{Switch off redundant lights and appliances}

Switching off lights in uninhabited parts of the house, and in spaces where natural light can adequately provide the required illumination is a prospect for energy cut. This can be done 
either automatically or manually by switch. Provision of lighting switches at strategic points can aid manual switching. By utilizing diverse method of automatic controls such as motion detectors, occupancy sensors etc., lighting fittings can either be switched on or off automatically. Energy savings using such devices will prove significant. Programmable timers have the capability of saving up to about 10-30\% of lighting energy while occupancy sensors and photo sensors are capable of reducing energy consumption by 30-60 and 10-35\%, respectively [19].

\section{Removal of redundant fixtures}

Many buildings and rooms undergo reconstructions and modification. Such rooms may be reassigned and equipment in such rooms moved while the lighting arrangement is not correspondingly restructured. By implication, these lights become redundant and unneeded. If such redundant fixtures are removed and replaced, energy cost is reduced, and the replaced fixtures can be reused.

\section{Fixture delamping}

This basically involves removal of selected lamp fittings from existing light fixtures. The fittings may either be removed in a uniform outline all over the areas of concern to reduce overall illumination or identified lights that do not contribute to a task are removed.

\section{Lighting retrofitting}

Lighting retrofitting entails replacing an existing inefficient lamp with a new and more efficient one. Although the initial capital for retrofitting is higher as compared to delamping, it offers a long-term advantage of low energy consumption.
Renewable energy potentials in Nigeria

Nigeria is endowed with substantial conventional energy resources (tar sands, natural, crude oil, and coal) as well as huge sources of renewable energy which largely includes solar energy, wind energy, small hydroelectric energy potentials, biomass, untapped hydrogen exploitation and development of geothermal and ocean energy technologies [20-22].

\section{Solar resource potential}

The annual average solar radiation in Nigeria varies from approximately $12.6 \mathrm{MJ} / \mathrm{m}^{2} /$ day $\left(3.5 \mathrm{kWh} / \mathrm{m}^{2} /\right.$ day $)$ in the coastal latitudes to approximately $25.2 \mathrm{MJ} / \mathrm{m}^{2} /$ day $(7.0 \mathrm{kWh} /$ $\mathrm{m}^{2} /$ day) in the extreme north [20]. The solar data for the site under consideration were collected from the International Institute of Tropical Agriculture (IITA) and Nigerian Meteorological Agency (NIMET). Figure 1 shows the monthly average daily solar radiation of the site under consideration.

\section{Wind resource potential}

Wind speeds in Nigeria range from as low as 1.4 to $3.0 \mathrm{~m} / \mathrm{s}$ in the south and 4.0 to $5.12 \mathrm{~m} / \mathrm{s}$ in the far north [20-22]. Wind speeds in Nigeria are usually weak in the south with the exemption of the coastal regions and offshore regions. Wind speed hits its highest point between April and August. Preliminary research shows that total definite utilizable wind energy reserve at $10 \mathrm{~m}$ height, varies between $8 \mathrm{MWh} /$ year in Yola to $51 \mathrm{MWh} /$ year in the mountain areas of Jos Plateau, while in Sokoto it is as high as $97 \mathrm{MWh} /$ year [23]. Based on data obtained from IITA, the wind speed for the site location shows a minimum of $0.86 \mathrm{~m} / \mathrm{s}$ in the month of January and maximum of $1.34 \mathrm{~m} /$ $\mathrm{s}$ in May which is shown in Fig. 2.

Fig. 1 Monthly solar radiation

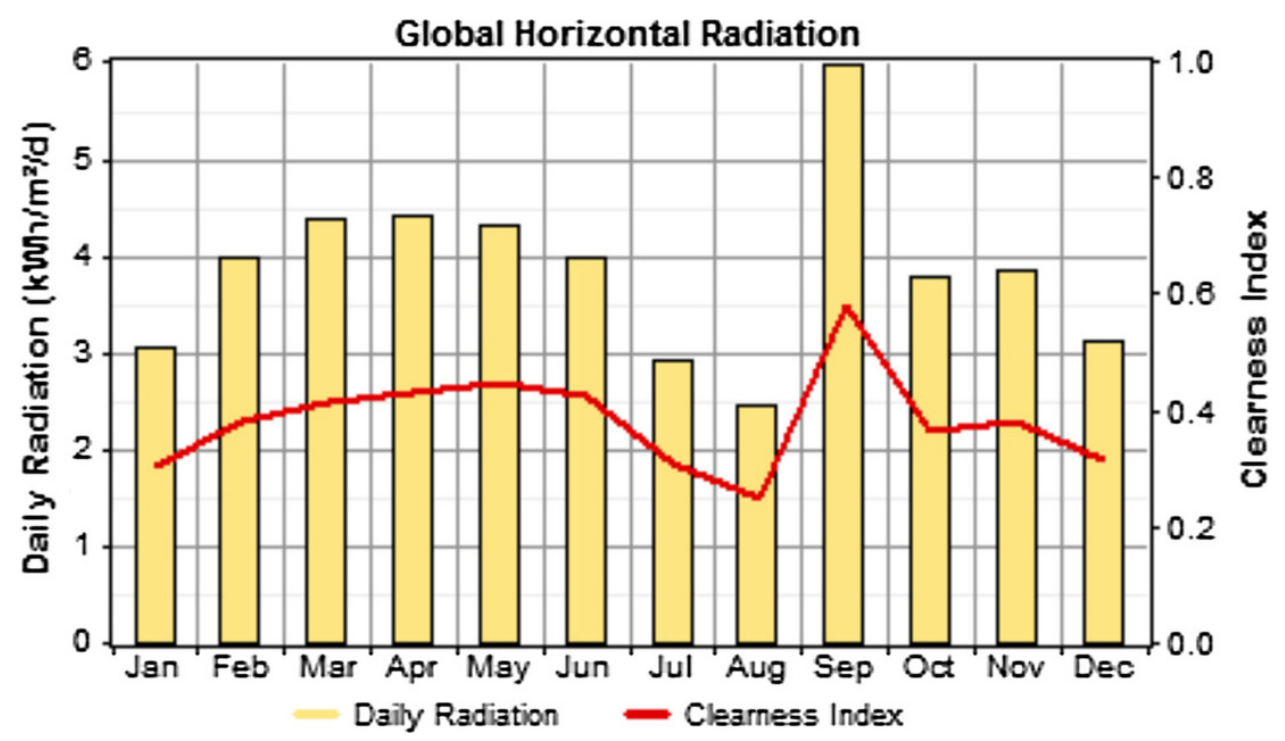


Fig. 2 Wind resources

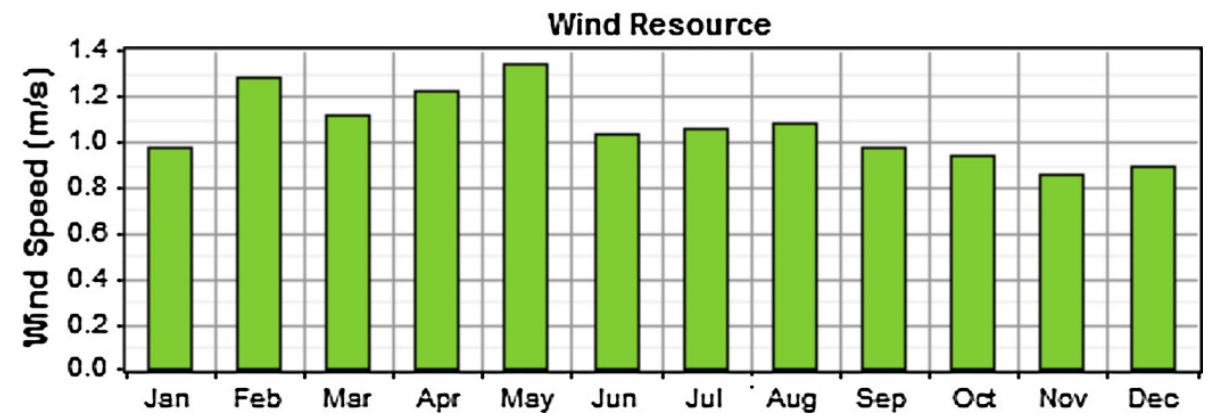

\section{Electricity supply in Ibadan}

The Nigerian Electricity Supply industry has six generating companies, one transmission company and eleven distribution companies. These distribution companies are: Lagos, Ikeja, Abuja, Benin, Jos, Yola, Port Harcourt, Enugu, Kano, Kaduna and Ibadan. Out of these distribution companies, the Ibadan Electricity Distribution Company, IBEDC, is the largest electricity distribution network. It has 22 Business Units spread across its franchise area. Among these 22 Business Units, 5 are in the neighboring Ogun State. These are: Ota, Olumo, Ijeun, Sagamu and Ijebu-Ode Business Units. Eight are in Oyo State namely: Akanran, Apata, Dugbe, Molete, Monatan, Ogbomosho, Ojoo and Oyo Business Units. Five Business Units are in Osun State; namely Ede, Ikirun, Ilesa, Ile-Ife and Osogbo Business Units. While there are four located in Kwara State; these are Baboko, Challenge, Jebba and Omu-Aran Business Units. Currently, IBEDC has a total customer population of $1,136,593$ and a total installed energy capacity of 720.8 MW. Its current electricity infrastructure in Ibadan is as shown in Table 1; thus it is quite herculean for the company to supply all the communities within its network due to insufficient power injected to the district. This company however plans to quickly expand its customer base by reaching out to the rural communities within its coverage area.

The case study for this work, i.e., Iporin, is a village settlement near Ibadan. Meanwhile, it has been neglected without any form of electricity supply from the utility company but the community could be electrified through

Table 1 Infrastructure for electrification in Ibadan metropolis

\begin{tabular}{lll}
\hline S/N & Parameter & Quantity \\
\hline 1 & Total capacity of $330 / 132 / 33 \mathrm{kV}$ lines & 360MVA \\
2 & Total capacity of $132 / 33 \mathrm{kV}$ lines & $60 \mathrm{MVA}$ \\
3 & Total capacity of $33 / 11 \mathrm{kV}$ lines & $270 \mathrm{MVA}$ \\
4 & Total number of $330 \mathrm{kV}$ substations & 1 \\
5 & Total number of $132 \mathrm{kV}$ substations & 2 \\
6 & Total number of $33 / 11 \mathrm{kV}$ injection stations & 11 \\
\hline
\end{tabular}

the hybrid energy system (using renewable energy with fossil fuel). This is informed by the available information on the local availability of both solar and wind energy sources in the community.

\section{Methods}

\section{DSM indices}

Two basic indices are used in evaluating both technical and economic benefits of DSM [14]. These are namely, demand side management quality index (DSMQI) for quantifying the technical effects, and the demand side management appreciation index (DSMAI) for economic effects [14]. These indices will help stake holders such as engineers; economists; management personnel and consumers appreciate the rationale behind a particular DSM technique.

\section{Demand side management quality index (DSMQI)}

Demand side management quality index (DSMQI) is an index that quantifies the technical benefits attached to a particular DSM programmes [14].

DSMQI $=\frac{\mathrm{kVA}_{\text {WODSM }}}{\mathrm{kVA}_{\text {WDSM }}}$

a DSMQI > 1 is good; the higher the ratio, the higher the benefit of the DSM programme; where $\mathrm{kVA}_{\text {WDSM }}$ and $\mathrm{kVA}_{\text {WODSM }}$ is the $\mathrm{kVA}$ rating with and without DSM, respectively.

\section{Demand side management appreciation index (DSMAI)}

Demand side management appreciation index (DSMAI) is an index that highlights the economical gain of DSM programmes [14]. DSMAI is defined as

$\operatorname{DSMAI}_{\mathrm{kWh}}=\frac{\mathrm{CkWh}_{\text {WODSM }}}{\mathrm{CkWh}_{\mathrm{WDSM}}}$

$\mathrm{CkWh}_{\text {WDSM }}$ and $\mathrm{CkWh}_{\text {WODSM }}$ and the cost of $\mathrm{kWh}$ with and without DSM, respectively. 
Load profile

Estimating the potential load demand, patterns of consumption are needed to determine the size of investment needed for electrification. In Nigeria, available data bank with regard to electricity consumption in rural communities is nevertheless very limited.

The village of iponrin which is a rural community in Ibadan, Oyo state with about 54 houses is however an example of such community. Ibadan is a city situated in south-western part of Nigeria, $128 \mathrm{~km}$ inland northeast of Lagos and $530 \mathrm{~km}$ southwest of Abuja, the federal capital. It is a famous transit point between the coastal region in the south and the areas to the north. There are 11 Local Governments in the city of Ibadan consisting of 5 urban local governments and 6 semi-urban/rural local governments.

Ibadan is a major center for trade in both food and cash crops such as; in cassava, cocoa, cotton, timber, rubber as well as palm oil. The key industries in the city include the processing of agricultural products; flourmilling, leather-working and furniture-making etc. These activities require access to constant electricity supply. Owing to the fact that its rural areas are a major source of agricultural produce to the southwest region of the country, Ibadan was chosen as a case study. In addition, there is notable accessibility to both wind and solar resource data from the agricultural research center, i.e., international institute of Tropical Agriculture. More so, the proximity of the site under consideration to the University of Ibadan presents an opportunity for a regular fostering and assistance of researchers from the institution in the event of technical challenges.

The settlement of iporin is occupied majorly by farmers, few civil servants, traders and artisans. The village is a few kilometers from the farm camp of Oyo state. Most of the buildings were built without the input of professionals and consultants in the field of electrical engineering and energy efficiency. At the time of construction of most of the buildings, energy efficiency and sustainability were not considered significant.

To investigate the potential demand for iporin community and to make the model more practical, field research was conducted in the settlement. Data are collected through personal interviews and distribution of energy audit assessment questionnaires (EAAQ) to residents and shop owners in the area under study. A total of 67 questionnaires were administered. Since there is no grid system, most of the residents and shop owners use petrol generator.

The community's lighting system had a different combination of inefficient lighting fixtures which includes $4 \mathrm{ft}$. fluorescent tubes bulbs, halogen lamps and incandescent bulbs. Approximately $89 \%$ of lighting fixtures of the community were inefficient incandescent bulbs and $100 \%$ of lighting fixtures in the shops were also using inefficient incandescent light bulbs. Even with their personal petrol generator, used lighting point was left on during the day. The electricity energy demand was estimated using the information on the questionnaire and a load demand curve was established using a specific demand factor depending on the hour of the day and equipment. Some of the appliances used in the community include; television, DVD players, refrigerators, pumping machine, etc.

The demand factor is necessary for estimation of the load profile. The demand factor is either the daily, monthly or annual ratio of number of houses using a particular appliance at a particular hour to the total number of houses that has the appliance. This can be estimated using Eq. 3.

demand factor (DF)

$$
\begin{aligned}
& =\frac{\text { no. of houses using appliance at that hour }}{\text { the total no. of houses with such functional appliance }} \\
& \text { for all case }: 1 \leq \mathrm{DF} \leq 0
\end{aligned}
$$

The appliance hourly demand (AHD) at any hour is given as:

$$
\begin{aligned}
\operatorname{AHD}(\mathrm{kW})= & \text { DF } \times \text { no. of houses with appliance } \\
& \times \text { no. of appliance per house } \\
& \times \text { wattage of equipment }
\end{aligned}
$$

The hourly demand HD is given as the sum of all AHD operational at that hour

$\mathrm{HD}(\mathrm{kWh})=\sum_{t} \mathrm{AHD}$

where $t$ is the hour under consideration (e.g., 12 a.m.1 a.m., 1 a.m. -2 a.m., etc.). In this study $\mathrm{t}$ is taken as $1 \mathrm{~h}$.

By applying Eqs. 3-5, a load profile for the village was estimated. Without the application of energy-efficient measures, the daily profile of the village shows that a total of $297 \mathrm{kWh} /$ day was consumed with a peak load of $27.516 \mathrm{~kW}$ occurring between 8 p.m. and 9 p.m. Using a lower power rating lamp of 16,20 , and $25 \mathrm{~W}$ compact fluorescent bulb instead of $60 \mathrm{~W}$ incandescent lamp, $36 \mathrm{~W}$ florescent lamp and $105 \mathrm{~W}$ halogen lamps, respectively, to provide the same level of illumination, DSM can be achieved. Other DSM activities applied to the curve included putting off redundant light fitting during the day, discouraging the use of electric cooker, and some other heating element, and encouraging the use of fans instead of air conditioning system. The total daily consumption after the application of DSM dropped to $130 \mathrm{kWh}$ /day representing a decrease of $56.80 \%$. A peak load of $13 \mathrm{~kW}$ occurred between 6 p.m. and 7 p.m. which is shown in Fig. 3. 
Fig. 3 Estimated load profile of the village

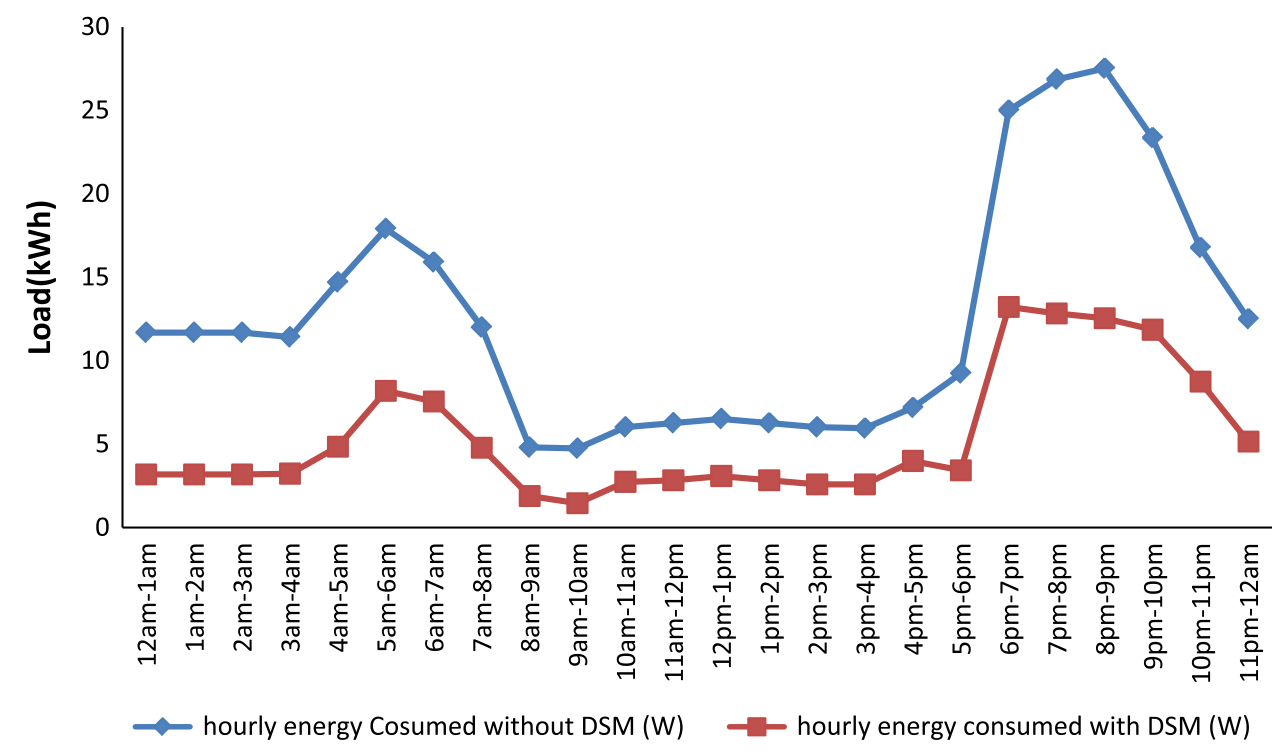

The hybrid system design and setup

There are several of ways of designing an optimal hybrid power system, each with varying levels of certainty. These methods vary from pencil and paper analysis and calculation by means of rules of thumb to sophisticated computersimulated energy production and system configuration dynamic predictions. Sizing of any hybrid systems involves a lot of multi-objective functions and hence a long iterative process. Considering the long iterative process and multiobjective function to be optimized, computer simulations are more accurate and recommended. In a nutshell, optimization and system modeling programs are imperative for minimizing the cost of power systems utilizing renewable energy. Some of the software available for this kind of simulation include: Hybrid2, HOMER, TRNSYS, EnergyPlus etc.

For the purpose of this work, the Hybrid Optimization Model for Electric Renewable (HOMER) is adapted. HOMER is optimization software developed by the NREL (National Renewable Energy Laboratory) and performs relative economic analysis on proposed and actual generation configuration [24]. Unlike most of the available software in market, HOMER uses a modified grid search algorithm for its simulations. It can eliminate some infeasible solutions without simulation, based on the results of earlier simulations and it recycles results from previous runs when possible. It also has an optional optimization algorithm, based on the open source software, Nomad. This eliminates the need for the user to specify the search space.

In view of the renewable energy resources (solar and wind) accessible at the site under consideration, the proposed hybrid system is based on a combination of PV panels, wind turbines, diesel generators and storage batteries as shown in Fig. 4. The battery bank is essentially needful for storage of electricity. It ensures constant supply of power to the load end in the event of power failure, cloudy weather and at night. In practice, the load profile will fluctuate on hourly and daily basis. Consequently, a $10 \%$ noise level is allowed for the estimated load so as to randomize the load profile and make it more practical. This scaled up the annual peak load to $39 \mathrm{~kW}$, as shown in Fig. 4.

Capital costs, replacement cost and operation and maintenance cost for the system components which include diesel generator, PV module, wind turbine, converter, are based on Ref. [25]. Table 2 gives the summary of various input cost.

Hybrid system control strategy and constraints

The project lifetime is projected as 25 years. At present, the annual interest rate in Nigeria is $12 \%$ [26]. Hence, $12 \%$ interest rate was used in this research. A capacity

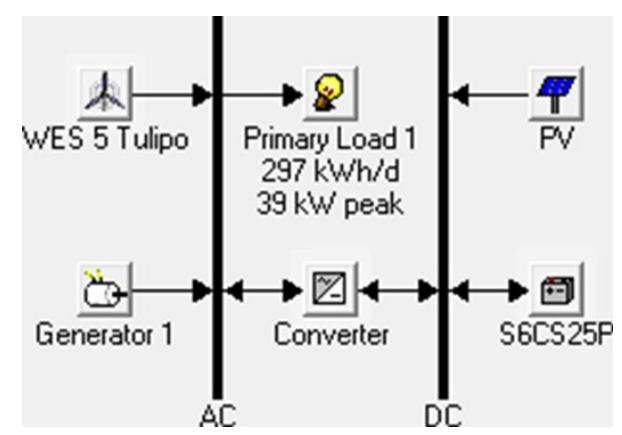

Fig. 4 Hybrid system configuration 
Table 2 Summary of input parameters

Fig. 5 Categorized optimization results

Fig. 6 Net present cost of component with DSM

\begin{tabular}{lcccll}
\hline Item & Size $(\mathrm{kW})$ & $\begin{array}{l}\text { Capital } \\
\text { cost }(\$)\end{array}$ & $\begin{array}{l}\text { Replacement } \\
\text { cost }(\$)\end{array}$ & $\begin{array}{l}\text { Operating and } \\
\text { maintenance } \\
\text { cost }(\$ / \text { year })\end{array}$ & $\begin{array}{l}\text { Life time } \\
\text { (years) }\end{array}$ \\
\hline PV module & 1 & 1,125 & 100 & 2 & 20 \\
Wind turbine & 1 & 1,875 & 1,750 & 6 & 15 \\
Converter & 3 & 250 & 225 & 1 & 15 \\
Battery & 1 & 500 & 473 & 25 & $9,645 \mathrm{kWh}$ \\
Diesel generator & 10 & 1,000 & 875 & 0.625 & $15,000 \mathrm{~h}$ \\
\hline
\end{tabular}

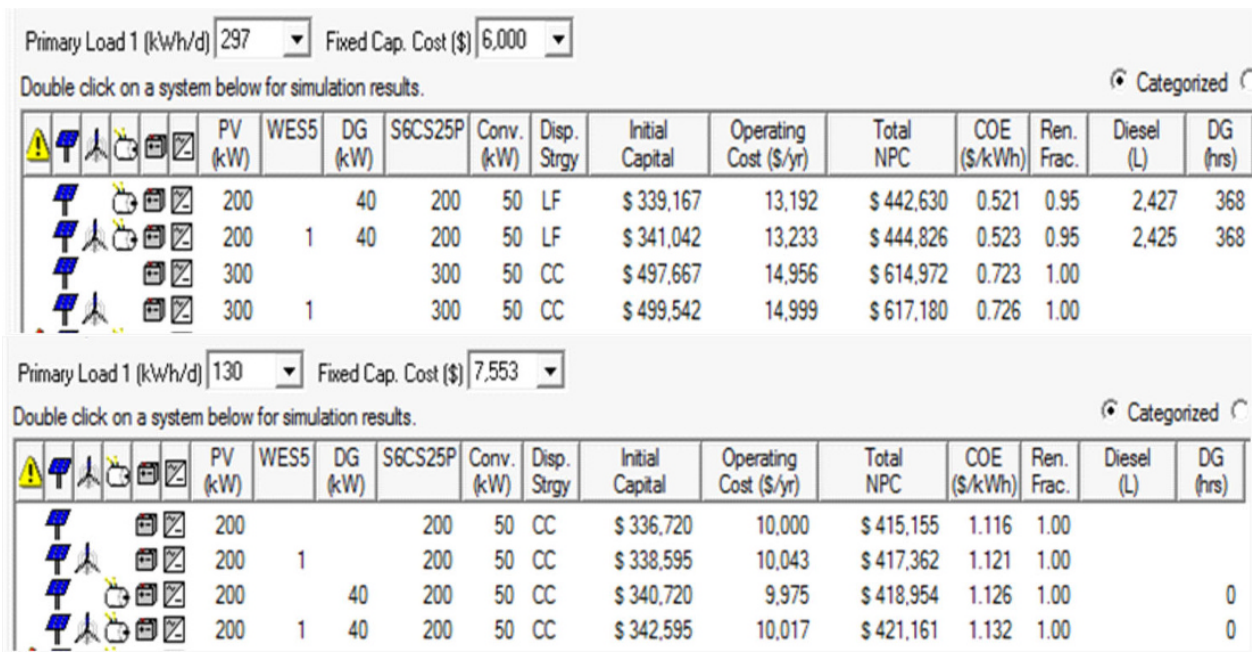

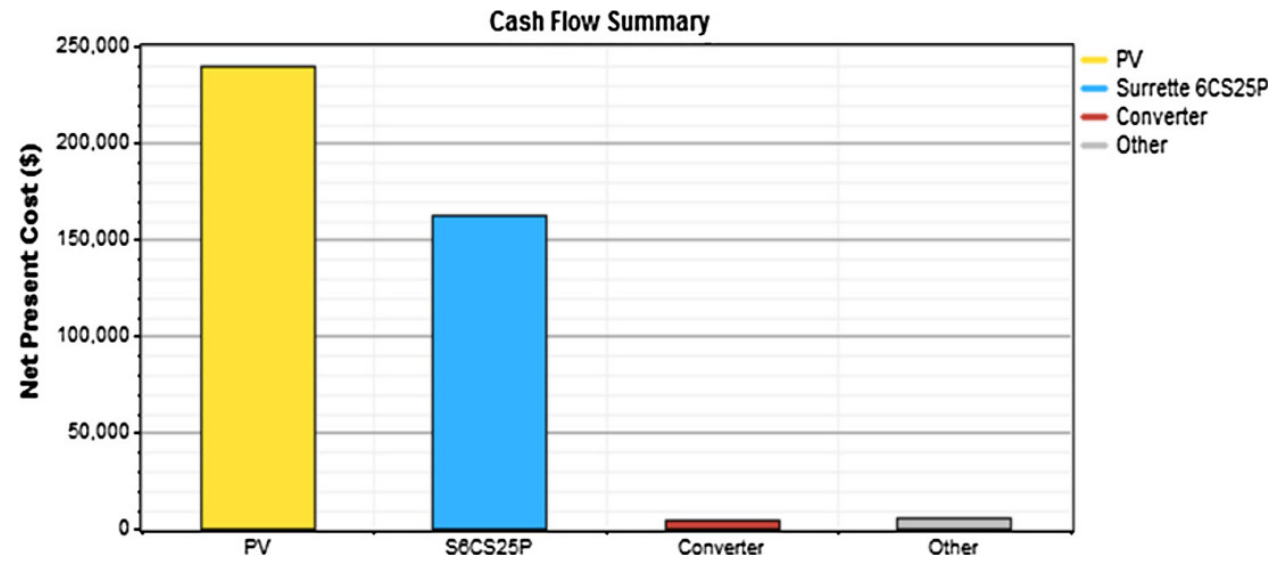

shortage of $0 \%$ was assumed and the operating reserve as a percentage of hourly load was $15 \%$. The operating reserve as a ratio of PV power output was pegged at $25 \%$.

HOMER has the capacity to model two control strategies: cycle charging and load following. HOMER chooses the optimal strategy based on factors such as size of the generator and battery bank, the fuel price, the O\&M cost of the generators, renewable power penetration in the system, and the properties of the renewable resources. A state of charge (SOC) of $80 \%$ was allowed, while both dispatch 
Fig. 7 Net present cost of component without DSM

Fig. 8 Net present cost of component with DSM

Fig. 9 Annualized cost of component without DSM
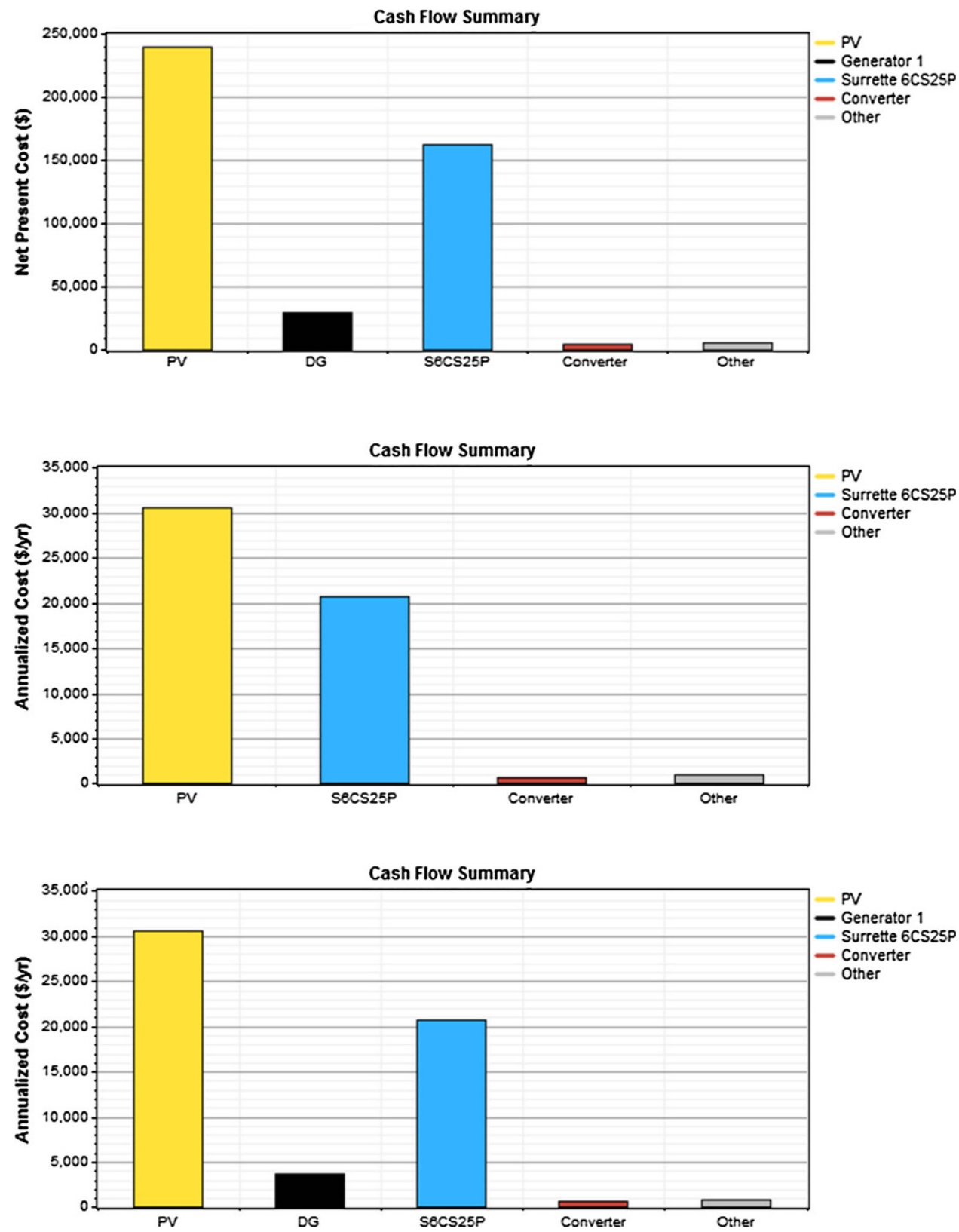

strategies - cycle charging and load following options were selected. Minimum renewable energy fraction was not selected for this research. Due to the current state of zero cost on $\mathrm{CO}_{2}$ emissions in Nigeria, this study did not consider emission constraints.

\section{Results and discussion}

Economic analysis

The categorized optimization results show that for a primary load of $297 \mathrm{kWh} /$ day, the PV/DG/Battery hybrid system can be considered as the most economical assuming no fluctuation in diesel price. According to Fig. 5, this system is made up of $200 \mathrm{~kW} \mathrm{PV}$ module, a $40 \mathrm{~kW}$ diesel generator, $50 \mathrm{~kW}$ converter and 200 Surrette 6 CS25 batteries with a dispatch strategy of load following. This indicates that the diesel generator would only operate to supply power to the loads, while the PV system charges the batteries. The net present cost NPC for this model is US $\$ 442,630$ and the cost of energy (COE) is US $\$ 0.521 / \mathrm{kWh}$. The diesel generator operated for $368 \mathrm{~h}$ using 2,427 L of diesel. For a primary load to which DSM is being applied (130 kWh/day), the optimal system configuration is PV/ Battery consisting of $200 \mathrm{~kW}$ PV module, $50 \mathrm{~kW}$ 
Table 3 Cost breakdowns and comparison

\begin{tabular}{lllll}
\hline & $\begin{array}{l}\text { System without } \\
\text { DSM }\end{array}$ & $\begin{array}{l}\text { System with } \\
\text { DSM }\end{array}$ & Savings & Unit \\
\hline Initial cost & 339,167 & 336,720 & 2,447 & $\$$ \\
O\&M & 49,650 & 42,435 & 7,215 & $\$ /$ year \\
Annualized cost & 56,435 & 52,932 & 3,503 & $\$ /$ year \\
Total NPC & 442,630 & 415,155 & 27,475 & $\$$ \\
Levilized COE & 0.521 & 1.116 & -0.595 & $\$ / \mathrm{kWh}$ \\
\hline
\end{tabular}

converter and 200 Surrette 6CS25 batteries with no diesel generator. The dispatch strategy is 'cycle charging'. The NPC for this configuration was reduced to US $\$ 415,155$ with a COE of US $\$ 1.116 / \mathrm{kWh}$. As compared to a load of $297 \mathrm{kWh} /$ day, the cost of energy increased due to the additional cost of $\$ 1,553$ being the cost of retrofitting. There was a net present cost savings of $\$ 27,475$ by applying DSM activities to the primary load. Figures 6, 7, 8 and 9 give the graphical representation of the net present cost and annualized cost of all components used with and without DSM. As compared to the load without DSM, there was a saving of $\$ 3,503$ in the annualized cost when DSM was applied.
The summary of the cost breakdowns and comparison for the two scenarios under consideration is shown in Table 3. Using Eqs. 1 and 2, the values of the DSM index were determined. The value of DSMQI was given as 2.15 , while that of DSMAI stood at 0.46 . A DSMQI of 2.15 is an indication of a great benefit of the demand side management activities. The value of DSMAI was low due to the large quantity of available excess energy generated by the application of DSM.

\section{Electricity production}

Figure 10 shows the percentage contribution to the total electricity produced by individual system source without the application of DSM. The PV supplies $98 \%$ of the annual electricity generated by the system with a capacity factor of $12.8 \%$. Generator with an overall contribution of $2 \%$ to electricity production has a capacity factor of $1.43 \%$ while operating for $368 \mathrm{~h} /$ year. As shown in Fig. 11, with the application of energy efficiency measures, an energy system configuration with a renewable energy fraction of unity consisting of a $200 \mathrm{~kW}$ PV module, $50 \mathrm{~kW}$ converter and 200 Surrette $6 \mathrm{CS} 25$ batteries with no
Fig. 10 Monthly average electricity production without DSM
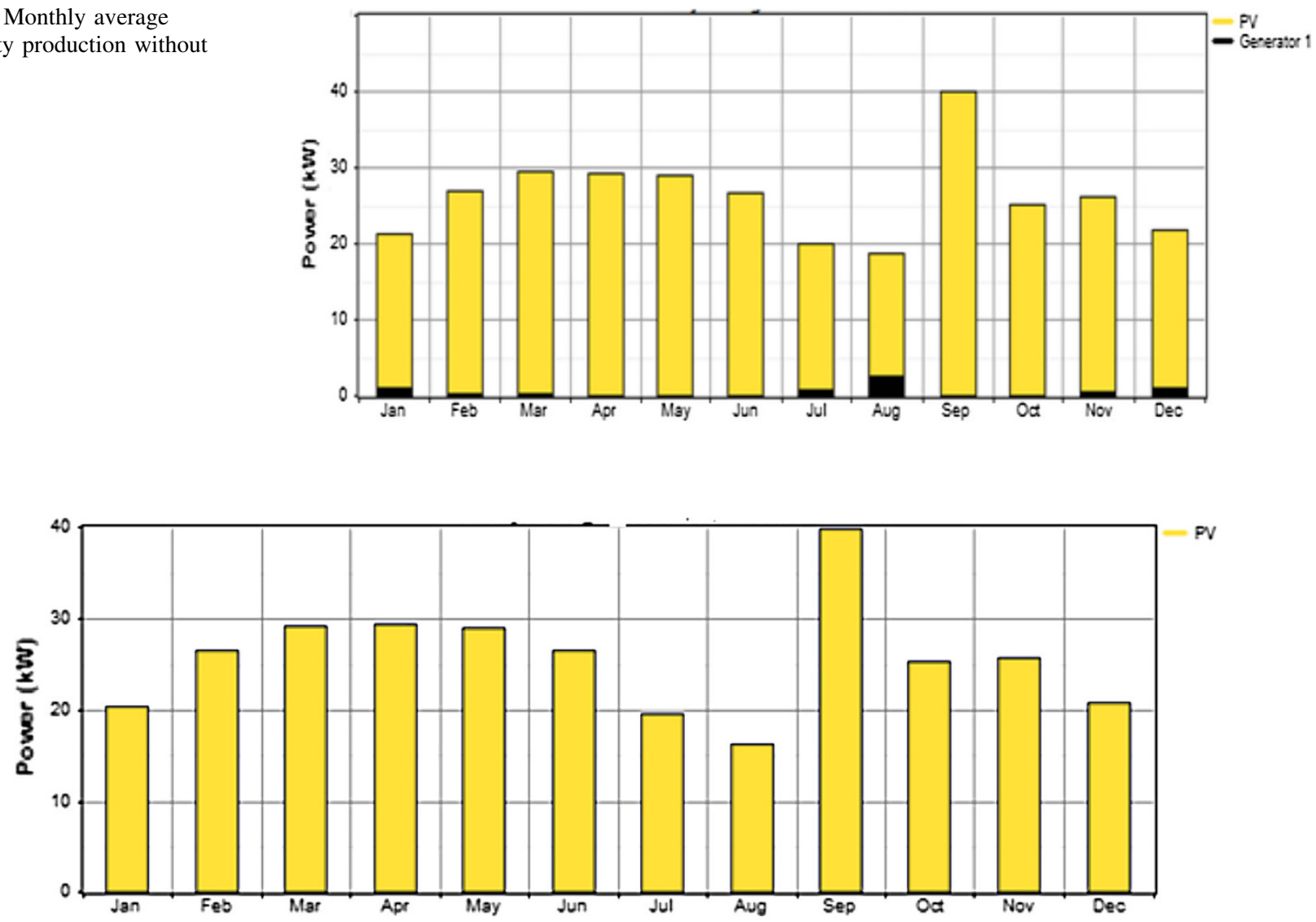

Fig. 11 Monthly average electricity productions with DSM 
Table 4 Comparison of simulation results of electricity production $(\mathrm{kWh} /$ year)

\begin{tabular}{lcrrrr}
\hline Quantity & \multicolumn{2}{c}{ Load without DSM } & & \multicolumn{2}{c}{ Load with DSM } \\
\cline { 2 - 3 } & $\mathrm{kWh} /$ year & $\%$ & & $\mathrm{kWh} /$ year & $\%$ \\
\hline AC primary load & 108,405 & 100 & & 47,450 & 100 \\
PV array & 224,155 & 98 & & 224,155 & 100 \\
Diesel generator & 4,997 & 2 & & 0 & 0 \\
Total energy & 229,152 & 100 & & 224,155 & 100 \\
Excess energy & 88,977 & 38 & & 162,144 & 72.3 \\
\hline
\end{tabular}

Table 5 Comparison of emission of both models

\begin{tabular}{lll}
\hline Pollutant & \multicolumn{2}{l}{ Emissions (kg/year) } \\
\cline { 2 - 3 } & Load without DSM & Load with DSM \\
\hline $\mathrm{CO}_{2}$ & 6,391 & 0 \\
$\mathrm{CO}$ & 15.8 & 0 \\
Unburned hydrocarbons & 1.75 & 0 \\
Particulate matter & 1.19 & 0 \\
$\mathrm{SO}_{2}$ & 12.8 & 0 \\
$\mathrm{NO}_{X}$ & 141 & 0 \\
\hline
\end{tabular}

diesel generator turns out to be the optimal configuration. The month of August had the highest percentage of diesel generation input because the solar radiation for the month of August was the lowest. Details of this are given in Table 4.

\section{Emission analysis}

Emissions resulting from both models (with and without DSM) are given in Table 5. Results show zero emission for the system without DSM due to $100 \%$ renewable fraction. PV/DG/Battery hybrid system (model without DSM) with a diesel generator operating for $368 \mathrm{~h} /$ year consuming $2,742 \mathrm{~L}$ fuel consumption per annum emits $6,391 \mathrm{~kg} / \mathrm{year}$ of $\mathrm{CO}_{2}, 15.8 \mathrm{~kg} /$ year of $\mathrm{CO}, 1.75 \mathrm{~kg} /$ year of unburned hydrocarbon, $1.19 \mathrm{~kg} /$ year of particulate matter, $12.8 \mathrm{~kg} /$ year of $\mathrm{SO}_{2}$, and $141 \mathrm{~kg}$ of $\mathrm{NO}_{X}$ annually into the environment.

\section{Conclusion}

Optimization of standalone hybrid energy system considering DSM activities has been conducted. By applying various energy efficiency activities, the load for a typical community was reduced by at least $56.8 \%$. A comparative simulation shows that the most feasible configuration for load with and without DSM is PV/battery and PV/DG/ battery, respectively. The technical analysis of both configuration carried out in this paper shows the feasibility of a $100 \%$ renewable energy fraction electricity production for rural electrification in Ibadan Nigeria. Hybrid PV/battery model, though with extra cost of retrofitting and higher levilized cost of energy, has a lower initial cost, operation and maintenance cost, annualized cost and overall costs throughout the lifespan of the project-NPC. The high DSM index from the result shows that the energy efficiency measures activities are quite beneficial. Application of energy-efficient activities gave a load/hybrid energy configuration with decreased carbon emission at the site under consideration by $100 \%$ as compared to the case without DSM.

This study shows that the potential of DSM and renewable energy sources especially solar energy cannot be ignored. This work has shown the ignorance of rural dwellers in developing world on the subject of energy efficiency techniques and its importance. Therefore, this study presents opportunities in energy auditing for energy planner and auditors to explore in future researches. Certain percentage of energy demand in rural areas in Nigeria may be supplied by exploration of PV systems. Overall, the DSM activities proved to be more economical and environmental friendly.

\section{Recommendation}

The implementation and sustainability of this project will rely heavily on the law that establishes the Rural Electrification Agency (REA). With the availability of the Rural Electrification Fund (REF) which is administered by the REA, it is thus suggested that REA takes up the responsibility of implementing this project for Iporin as a pilot project which can then be extended to other rural communities in other parts of Nigeria (where wind and solar energy sources are available at economic quantity).

For this project to be sustainable, there must be adequate and timely scheduled/preventive maintenance, prompt payment of electricity bills by its consumers as well as consistent energy planning and energy audits (by the REA) to increase the installed capacity, so as to avoid overloading the current design. Meanwhile, the relevant researchers (especially from the closeby University of Ibadan and within the REA) need to collaborate with the beneficiary community so as to ensure sustainability of the project.

Authors' contributions T.O. conceived the study, participated in its design and coordinated the general supervision of the research group. P.O. participated in the design of the sequence, arrangement and drafting of the manuscript and structuring of the results. O.M 
participated in the site visitation, data analysis and interpretation of data/results.

Open Access This article is distributed under the terms of the Creative Commons Attribution License which permits any use, distribution, and reproduction in any medium, provided the original author(s) and the source are credited.

\section{References}

1. Nigeria Over 167 Million Population. Implications and challenges. http://www.population.gov.ng/index.php/84-news/latest/ 106-nigeria-over-167-million-population-implications-and-chal lenges. Accessed 12 March 2013

2. Givler, T., Lilienthal, P.: Using HOMER software, NREL's micropower optimization model, to explore the role of gen-sets in small solar power systems case study: Sri Lanka. [online] NREL/ TP-710-36774 (2005), pp. 1-25. http://www.osti.gov/bridge

3. Gül, T.: Integrated analysis of hybrid systems for rural electrification in developing countries. M.Sc. Thesis, Department of Energy Processes Royal Institute of Technology, Stockholm (2004)

4. Lal, Raturi: Techno-economic analysis of a hybrid mini-grid system for Fiji islands. Int. J. Energy Environ. Eng. 3, 10 (2012)

5. World Bank, "Nigeria," World Bank, February 2013 [online]. http://data.worldbank.org/country/nigeria. Accessed March 2013

6. Cecelski, E.: Enabling equitable access to rural electrification, current thinking and major activities in energy, poverty and gender (2002). http://www.energia.org [online]. http://www.ener gia.org/fileadmin/files/media/EN112002_cecelski.pdf. Accessed March 2013

7. Abolarin, S.M., Gbadegesin, A.O., Shitta, M.B., Yussuff, A., Eguma, C.A., Ehwerhemuepha, L., Adegbenro, O.: A collective approach to reducing carbon dioxide emission: a case study of four University of Lagos Halls of residence. Energy Build. 61, 318-322 (2013)

8. Ghodmare, K., Dharme, A., Ghatol, A.: Techno-economic analysis of DSM using capacitors in reral sector (2008)

9. Babu, P.R., Divya, V.P.S.: Mathematical modelling and DSM techniques applied to a medium scale milk industry. In: Rudas, I., Mastorakis, N. (eds.) WSEAS international conference. Proceedings. Mathematics and computers in science and engineering. No. 9. World Scientific and Engineering Academy and Society (2009)

10. Bonneville, E., Rialhe, A.: Demand side management for residential and commercial end-users. Effic. Eco-Des. (2006)

11. Strbac, G.: Demand side management: benefits and challenges. Energy Policy 36(12), 4419-4426 (2008)

12. Torriti, J., Hassan, M.G., Leach, M.: Demand response experience in Europe: policies, programmes and implementation. Energy 35(4), 1575-1583 (2010)

13. Exarchakos, L., Leach, M., Exarchakos, G.: Modelling electricity storage systems management under the influence of demand-side management programmes. Int. J. Energy Res. 33(1), 62-76 (2009)
14. Dharme, A., Ghatol, A.: Demand side management quality index for assessment of DSM programs. In: Power systems conference and exposition, 2006. PSCE'06. 2006 IEEE PES. IEEE (2006)

15. Lal, D.K., Dash, B.B., Akella, A.K.: Optimization of PV/wind/ micro-hydro/diesel hybrid power system in HOMER for the study area. Int. J. Electr. Eng. Inf. 3(3) (2011)

16. Nema, P., Nema, R.K., Rangnekar, S.: PV-solar/wind hybrid energy system for GSM/CDMA type mobile telephony base station. Int. J. Energy Environ. 1(2), 358-366 (2010)

17. Shafiullah, G.M., Amanullah, M.T.O., Shawkat Ali, A.B.M., Jarvis, D., Wolfs, P.: Economic analysis of hybrid renewable model for subtropical climate. Int. J. Therm. Environ. Eng. 1(2), 57-65 (2010)

18. Bajpai, P., Kumar, S., Kishore, N.K.: Sizing optimization and analysis of a stand-alone WTG system using hybrid energy storage technologies. In: Proceedings of the International Conference on IEEE. Energy and Sustainable Development: Issues and Strategies (ESD) (2010)

19. Baker, J.A.: Energy management control system. U.S. Patent No. 5,962,989 (1999)

20. Oyedepo, S.O.: Efficient energy utilization as a tool for sustainable development in Nigeria. Int. J. Energy Environ. Eng. 3(11), $1-12(2012)$

21. Sambo, A.S.: Strategic developments in renewable energy in Nigeria. Int. Assoc. Energy Econ. 16 (2009)

22. Nwulua, N.I., Agboolab, O.P.: Utilizing renewable energy resources to solve Nigeria's electricity generation problem. Int. J. Therm. Environ. Eng. 3(1), 15-20 (2011)

23. Oyedepo, S.O.: On energy for sustainable development in Nigeria. Renew. Sustain. Energy Rev. 16(5), 2583-2598 (2012)

24. Lilienthal, P., Gilman, P., Lambert, T.: Getting started guide for HOMER legacy (Version 2.68). HOMER Energy, Boulder (2011)

25. Bhuiyan, M.A.M., Deb, A., Nasir, A.: Optimum planning of hybrid energy system using HOMER for rural electrification. Int. J. Comput. Appl. 66(13), 45-52 (2013)

26. Nigeria Interest Rate. http://www.tradingeconomics.com/nigeria/ interest-rate. Accessed 17 Dec 2013

T. O. Akinbulire is currently an Associate Professor of Power systems and holds a PhD in Power Systems Engineering from the Department of Electrical Electronic Engineering University of Lagos. His area of interest includes power system analysis, design, control and reliability as well as Renewable Energy.

P. O. Oluseyi $(\mathrm{PhD})$ is a research fellow/Lecturer in Power System Engineering at the Department of Electrical/Electronics Engineering of the University of Lagos, Nigeria. His research interest includes Energy Efficiency and Management, Power Networks Analysis/ Optimization and Renewable/Zero Energy Applications in buildings.

O. M. Babatunde is a postgraduate Student in the Department Electrical/Electronic Engineering University of Lagos. He is a Mechanical and Electrical (M\&E) consultant for building services. He specializes in hybrid energy system and energy-efficient designs for buildings. 